\title{
Tear film and ocular surface alterations in chronic users of antiglaucoma medications
}

\author{
Alteração do filme lacrimal e superfície ocular em usuários crônicos \\ de medicação antiglaucomatosa
}

\author{
Lina do Prado Baffa ${ }^{1}$ \\ Jose Reinaldo da Silva Ricardo ${ }^{2}$ \\ Ana Carolina Dias ${ }^{3}$ \\ Carolina Maria Módulo ${ }^{4}$ \\ Alexandre Martins Braz \\ Jayter Silva de Paula ${ }^{6}$ \\ Maria de Lourdes Veronese Rodrigues ${ }^{7}$ \\ Eduardo Melani Rocha ${ }^{8}$
}

Department of Ophthalmology, Otorrinolaringology and Head\&Neck Surgery Faculty of Medicine of Ribeirão Preto - Universidade de São Paulo.

${ }^{1}$ Residente de Oftalmologia do Hospital das Clínicas da Faculdade de Medicina da Universidade de São Paulo USP - Ribeirão Preto (SP) - Brasil.

${ }^{2}$ Residente de Oftalmologia do Hospital das Clínicas da Faculdade de Medicina da USP - Ribeirão Preto (SP) Brasil.

${ }^{3}$ Pós-graduanda Departamento de Oftalmologia, Otorrinolaringologia e Cirurgia de Cabeça e Pescoço do Hospital das Clínicas da Faculdade de Medicina da USP Ribeirão Preto (SP) - Brasil.

${ }^{4}$ Aluna de iniciação científica do Departamento de Oftalmologia, Otorrinolaringologia e Cirurgia de Cabeça e Pescoço da Faculdade de Medicina da USP - Ribeirão Preto (SP) - Brasil.

${ }^{5}$ Aluno de iniciação cientísfica do Departamento de Oftalmologia, Otorrinolaringologia e Cirurgia de $\mathrm{Ca}$ beça e Pescoço da Faculdade de Medicina da USP Ribeirão Preto (SP) - Brasil.

${ }^{6}$ Professor Doutor do Departamento de Oftalmologia, Otorrinolaringologia e Cirurgia de Cabeça e Pescoço da Faculdade de Medicina da USP - Ribeirão Preto (SP) - Brasil.

${ }^{7}$ Professora Associada do Departamento de Oftalmologia, Otorrinolaringologia e Cirurgia de Cabeça e Pescoço da Faculdade de Medicina da USP - Ribeirão Preto (SP) - Brasil.

${ }^{8}$ Professor Associado do Departamento de Oftalmologia, Otorrinolaringologia e Cirurgia de Cabeça e Pescoço da Faculdade de Medicina da USP - Ribeirão Preto (SP) - Brasil.

Corresponding author: Eduardo M. Rocha. Departamento de Oftalmologia - FMRP - São Paulo University - Av. Bandeirantes, 3.900 - Ribeirão Preto (SP) CEP 14049-900

E-mail: emrocha@fmrp.usp.br

Recebido para publicação em 07.06.2006

Última versão recebida em 27.09.2007

Aprovação em 28.09.2007

The authors have no financial interest in the study. Financial Support: CNPq, FAEPA and FAPESP

\begin{tabular}{l} 
ABSTRACT \\
\hline Purpose: Tearfilm can be altered by chronic medications that may disrupt \\
the equilibrium responsible for the functioning of the lacrimal gland and \\
ocular surface. The purpose of this study was to determine if \\
antiglaucomatous chronic treatment induced alterations in the tear film \\
and ocular surface. Methods: After informed consent, 21 patients using \\
antiglaucomatous eye drops for more than 8 months and 20 age- and sex- \\
matched volunteers without eye and systemic medications (control \\
group) were enrolled. The data of ocular discomfort, fluorescein and \\
lisamine green staining, tear film break-up time and Schirmer test were \\
collected and compared by Student's $t$ test. The impression cytology \\
data were graded and compared by chi-square test. Results: Patients \\
chronically using antiglaucomatous medications presented with sig- \\
nificant higher fluorescein staining (p=0.003), lisamine green staining \\
(p=0.02) and lower TFBUT (p=0.001). The other compared parameters, \\
including impression cytology were similar between the treated and \\
control group (p>0.05). Conclusions: The present study shows that the \\
tear film and the ocular surface are altered in patients under antiglauco- \\
matous medications. In common, all medications were preserved with \\
benzalkonium chloride. Efforts to minimize the adverse effects of \\
chronic use of antiglaucomatous drugs must be addressed.
\end{tabular}

Keywords: Benzalkonium compounds/administration \& dosage; Benzalkonium compounds/ drug effects; Timolol/administration \& dosage; Timolol/drug effects; Tears/drug effects; Optic disk/drug effects; Glaucoma/drug therapy; Dry eye syndromes; Indicators and reagents

\section{INTRODUCTION}

The tear film is a key element for the quality of optical image and ocular surface health and may be altered by several conditions that disrupt the homeostasis provided by the neuroimmunoendocrine network ${ }^{(1-3)}$.

Along the last decade, an increase in options for topical glaucoma therapy raised concern about compliance, persistency, side effects and complications regarding further treatments ${ }^{(4-6)}$.

The potential damage to the tear film and ocular surface by chronic and/or addition of glaucoma medications has been suggested by experimental and observational studies. Authors observed higher prevalence of symptoms, higher expression of inflammatory markers and relative reduction of some parameters of tear secretion ${ }^{(7-10)}$.

Dry eye and ocular surface damage are the major concerns related to this chronic, sight-threatening disease since they may have an impact on all those parameters that affect the success of glaucoma treatment ${ }^{(5,7)}$. 
Since antiglaucomatous drugs are analogs to neurotransmitters, pro-inflammatory or enzymatic mediators they may interfere in the neuroimmunoendocrine network, disrupting inflammatory and secretory actions. Moreover, benzalkonium chloride as preservative, may induce inflammation or reduce secretion ${ }^{(11-12)}$.

Even glaucoma itself has been hypothesized to be related to dry eye and ocular surface disorder, however no controlled recent studies compared the status of glaucoma patients under chronic topical medications to control individuals in a community-based clinical setting ${ }^{(10-13)}$.

The aim of the present study is to evaluate parameters of ocular surface and tear film of glaucoma patients under present actual chronic topical therapy compared to control individuals.

\section{METHODS}

\section{Study design}

Twenty-one patients followed at the Glaucoma Clinic participated in the present study. Eye examination was performed and compared to 20 control individuals who accepted to participate. Signed informed consent was obtained from all participants.

The study was approved by the University Hospital Ethics Committee (number 12210/2004) and respected the Declaration of Helsinki.

Information related to systemic disease and past ocular history, including glaucoma was recorded from patient chart and checked during the application of the questionnaire. Patients with chronic systemic disease, other ocular disease, past history of ocular surgery or conflicting data were not included.

The control group was selected among age- and gendermatched individuals without systemic disease and past history of ocular surgery or topical medication.

\section{Evaluation}

Patients and controls were submitted to a routine history and examination followed by environmental questionnaire with 10 questions and score range from 0 to 6 , from absent to severe discomfort (Table 1). Tear film and ocular surface examination consisted of tear film break-up time (TFBUT), $2 \%$ fluorescein and $1 \%$ lisamine green staining, Schirmer test (Ophthalmus, São Paulo, Brazil) with topical anesthesia, according to previously described guidelines ${ }^{(14)}$.

\section{Impression cytology}

The impression cytology was performed collecting conjunctival cells with a Millipore filter paper (Millipore, Billerica, MA, USA). Papers were transferred to gelatin-coated slides, fixed with 70\% ethanol, glacial acetic acid and formalin and stained with periodic acid-Schiff (PAS) and hematoxilin stain. Epithelium was evaluated in a masked fashion, according to a classification scheme whereas epithelial cells

Table 1. Items present in the environmental and discomfort ques-
tionnaire. Score ranged from 0 (never) to 6 (all times)
Questions
Light sensitivity
Sand sensation
Burning
Vision fluctuation
Vision improvement with eye drops
Tearing
Eye pain in the evening or in the morning
Blurred vision at driving or reading
Discomfort with wind
Discomfort with air conditioning

were classified into four stages, stage 0 (for normal morphology) to stage 3 (squamous metaplasia) ${ }^{(15)}$.

- Stage 0: small, round epithelial cells, large nuclei, abundant goblet cells.

- Stage 1: larger, polygonal cells, smaller nuclei, decreased number of goblet cells.

- Stage 2: larger, polygonal cells, smaller nuclei, smaller and rare goblet cells.

- Stage 3: large and polygonal cells, pycnotic or absent nuclei, absent goblet cells.

\section{Statistical analysis}

Data are expressed as means \pm SD (standard deviation). Comparisons were made using Student's $t$ test for continuous data (Statview software, Abacus, CA USA) and Fisher test for categorical data (Graphpad 3.0 software, Prism, San Diego, CA,USA). The used level of significance was $P<0.05$.

\section{RESULTS}

Both groups presented similar distribution related to age and sex ( $>0.05$ ) (Table 2). The ocular medications in use, at least during the last 8 months, were listed (Table 3 ).

The questionnaire of ocular discomfort indicated mean and standard deviation (SD) levels of $7.9 \pm 9.0$ for glaucomatous and $6.9 \pm 7.2$ for controls ( $\mathrm{p}=0.7$ ), fluorescein staining of $2.9 \pm 3.2$ for glaucomatous and $0.6 \pm 1.0$ for controls $(\mathrm{p}=0.003)$, lisamine green staining of $1.7 \pm 1.9$ for glaucomatous and $0.4 \pm 1.4$ for controls ( $\mathrm{p}=0.02$ ), TFBUT of $6.4 \pm 5.9$ seconds for glaucomatous and $14.1 \pm 2.4$ seconds for controls $(\mathrm{p}<0.05)$, Schirmer test of $14.5 \pm 12.0 \mathrm{~mm}$ for glaucomatous and $14.8 \pm 9.2 \mathrm{~mm}$ for controls $(\mathrm{p}=0.9)$.

Impression cytology findings were similar between both groups. ( $>0.05$ ) (Table 4).

\section{DISCUSSION}

The negative effects of antiglaucomatous medications on the ocular surface are known from previous studies and reports ${ }^{(11-13)}$. 


\begin{tabular}{|lccc|}
\hline \multicolumn{4}{|c|}{ Table 2. Age and sex distribution of patients and controls } \\
Group & Glaucomatous & Control & P \\
Age (years) & $64.1 \pm 12.9$ & $63.8 \pm 9.2$ & 0.9 \\
Gender & $71.4 \%$ male & $50 \%$ male & \\
\hline
\end{tabular}

\begin{tabular}{|c|c|c|}
\hline Medication & Frequency & Percentage \\
\hline $0.5 \%$ timolol maleate & qd & $38.10 \%$ \\
\hline $\begin{array}{l}0.5 \% \text { timolol maleate } \\
\text { and } 0.2 \% \text { brimonidine tartrate }\end{array}$ & BID & $14.29 \%$ \\
\hline $\begin{array}{l}0.5 \% \text { timolol maleate } \\
\text { and } 2 \% \text { pilocarpine hydrochloride }\end{array}$ & BID & $9.52 \%$ \\
\hline $2 \%$ pilocarpine hydrochloride & QID & $9.52 \%$ \\
\hline $\begin{array}{l}0.005 \% \text { latanaprost } \\
\text { and } 0.2 \% \text { brimonidine tartrate }\end{array}$ & qd & $4.76 \%$ \\
\hline $0.2 \%$ brimonidine tartrate & TID & $4.76 \%$ \\
\hline $\begin{array}{l}0.5 \% \text { timolol maleate } \\
\text { and } 0.2 \% \text { brimonidine tartrate } \\
\text { and } 0.03 \% \text { bimatoprost }\end{array}$ & BID & $4.76 \%$ \\
\hline $\begin{array}{l}0.5 \% \text { timolol maleate } \\
\text { and } 0.2 \% \text { brimonidine tartrate } \\
\text { and } 2 \% \text { dorzolamide hydrochloride } \\
\text { and } 0.005 \% \text { latanoprost }\end{array}$ & BID & $4.76 \%$ \\
\hline $\begin{array}{l}0.5 \% \text { timolol maleate } \\
\text { and } 2 \% \text { dorzolamide hydrochloride } \\
\text { and } 2 \% \text { pilocarpine hydrochloride } \\
\text { and } 0.03 \% \text { bimatoprost }\end{array}$ & BID & $4.76 \%$ \\
\hline $1 \%$ brinzolamide hydrochloride & TID & $4.76 \%$ \\
\hline \multicolumn{3}{|c|}{$\begin{array}{l}\text { BID= two times a day; } T I D=\text { three times a day; } q d=\text { once a day; } \\
\text { QID= four times a day }\end{array}$} \\
\hline
\end{tabular}

\begin{tabular}{|c|c|c|}
\hline & Glaucomatous & Controls \\
\hline Altered (stage I or higher) & $14(66.7 \%)$ & $10(47.6 \%)$ \\
\hline Non altered (stage 0 ) & 7 (33.3\%) & $11(52.4 \%)$ \\
\hline
\end{tabular}

The present study is the first that brings information about the effects in patients under actual and current therapy in real life conditions, which means non-selected patient or therapy. Previous studies have addressed this point but at that time, only a small number of possible prescriptions were available ${ }^{(12)}$.

Our study identified tear instability and epithelial damage, but no greater discomfort or reduced tear secretion. Previous studies have identified lower correlation among dry eye signs and between signs and symptoms ${ }^{(16)}$.

Moreover, contradictions in this specific subject related to glaucoma medications were also documented, since the hypothesis that dry eye syndrome (i.e., less tear secretion) related to glaucoma itself was brought up, but was not confirmed by the present study because Schirmer test was similar in glaucomatous and control individuals ${ }^{(10)}$.

In fact, our patients under chronic antiglaucomatous treatment have significant signs of epithelial damage, but not of ocular surface metaplasia. The present hypothesis suggested that prolonged treatment would induce changes in the number of goblet cells and epithelia; however, they may vary with different medications and combinations and duration of treatment ${ }^{(11,14,17)}$.

Due to the heterogeneity of available therapeutic modalities and the variable mechanisms of action, it would be difficult to determine the causes of ocular surface damage ${ }^{(18)}$.

A possible mechanism already suggested for antiglaucomatous medications and other chronic ocular medications such as artificial tears is related to benzalkonium chloride, a preservative that was present in all eye drops used in our study ${ }^{(7,19)}$.

The effects of glaucoma medication or its preservatives may induce a pro-inflammatory environment in the ocular surface with affects tissue cicatrization, drug pharmacokinetics, patient compliance and other factors that ultimately would affect intraocular pressure (IOP) control and disease progression ${ }^{(20-21)}$.

The reversibility of signs was previously reported rendering the medication preservative-free eye drops, however the sequels for the conjunctiva that would interfere in future clinical and surgical outcomes are unknown ${ }^{(17)}$.

Clinical studies related to dry eye syndrome and ocular surface damage, like the present study, are difficult in terms of methodology since there is no agreement between signs and symptoms, examinations have less sensitivity and the variability in the group is broad, due to heterogeneity of factors ${ }^{(22-24)}$.

This observation may indicate that comparisons including more diagnostic tests and larger samples would identify milder clinical differences with higher statistical significance.

\section{CONCLUSION}

In conclusion, the authors observed that in the current practice, glaucoma patients under prolonged treatment may have tear film instability and ocular surface epitheliopathy. Those events may interfere in treatment compliance and long-term control of IOP.

\section{RESUMO}

Objetivo: O filme lacrimal pode ser alterado por medicações crônicas, que podem comprometer o equilíbrio responsável pela função da glândula lacrimal e da superfície ocular. O objetivo desse estudo foi determinar se o tratamento crônico com drogas antiglaucomatosas induz alterações no filme lacrimal e superfície ocular. Métodos: Após o consentimento informado, 21 pacientes usando drogas antiglaucomatosas por mais de 8 meses e 20 voluntários com similar distribuição etária e por sexo, não usuários de medicação ocular ou sistêmica (grupo controle) foram incluídos. Os dados do desconforto ocular, coloração com fluoresceína e lissamina verde, tempo de ruptura do filme lacrimal e teste de Schirmer foram colhidos e analisados pelo teste $t$ de Student. A citologia de impressão foi avaliada e comparada pelo teste de qui-quadra- 
do. Resultados: Pacientes usando cronicamente medicação antiglaucomatosa apresentaram significativamente maior coloração por fluoresceína $(\mathrm{p}=0,003)$, lissamina verde $(\mathrm{p}=0,02)$ e menor TRFL ( $\mathrm{p}=0,001)$. Os outros parâmetros comparados, incluindo a citologia de impressão foram similares entre o grupo tratado e controle $(p>0,05)$. Conclusões: Esse estudo demonstra que o filme lacrimal e a superfície ocular estão alterados em usuários de medicação antiglaucomatosa. Essas medicações apresentam em comum o cloreto de benzalcônio como conservante. Esforços para minimizar efeitos adversos do uso crônico de drogas antiglaucomatosas devem ser considerados.

Descritores: Compostos de benzalcônio/administração \& dosagem; Compostos de benzalcônico/efeitos adversos; Timolol/administração \& dosagem; Timolol/efeitos adversos; Disco óptico/efeitos adversos; Glaucoma/quimioterapia; Síndrome do olho seco; Indicadores e reagentes

\section{REFERENCES}

1. Goto E, Yagi Y, Matsumoto Y, Tsubota K. Impaired functional visual acuity of dry eye patients. Am J Ophthalmol. 2002;133(2):181-6.

2. Wilder RL. Neuroendocrine-immune system interactions and autoimmunity. Annu Rev Immunol. 1995;13:307-38.

3. Rieger G. The importance of the precorneal tear film for the quality of optical imaging. Br J Ophthalmol. 1992;76(3):157-8.

4. Taylor SA, Galbraith SM, Mills RP. Causes of non-compliance with drug regimens in glaucoma patients: a qualitative study. J Ocul Pharmacol Ther. 2002;18(5):401-9

5. Broadway DC, Grierson I, O'Brien C, Hitchings RA. Adverse effects of topical antiglaucomatous medication. II. The outcome of filtration surgery. Arch Ophthalmol. 1994;112(11):1446-54. Comment in: Arch Ophthalmol. 1995;113(7):849-50.

6. Broadway DC, Grierson I, O'Brien C, Hitchings RA. Adverse effects of topical antiglaucoma medication. I. The conjunctival cell profile. Arch Ophthalmol.1994;112(11):1437-45.

7. Pisella PJ, Pouliquen P, Baudouin C. Prevalence of ocular symptoms and signs with preserved and preservative free glaucoma medication. Br J Ophthalmol. 2002;86(4):418-23.

8. de Jong C, Stolwijk T, Kuppens E, de Keizer R, van Best J. Topical timolol with and without benzalkonium chloride: epithelial permeability and auto- fluorescence of the cornea in glaucoma. Graefes Arch Clin Exp Ophthalmol. 1994;232(4):221-4

9. Ohtsuki M, Yokoi N, Mori K, Matsumoto Y, Adachi W, Ishibashi K, et al. [Adverse effects of beta-blocker eye drops on the ocular surface]. Nippon Ganka Gakkai Zasshi. 2001;105(3):149-54. Japanese.

10. Kuppens EV, van Best JA, Sterk CC, de Keizer RJ. Decreased basal tear turnover in patients with untreated primary open-angle glaucoma. Am J Ophthalmol. 1995;120(1):41-6.

11. Pisella PJ, Debbasch C, Hamard P, Creuzot-Garcher C, Rat P, Brignole F, et al. Conjunctival proinflammatory and proapoptotic effects of latanoprost and preserved and unpreserved timolol: an ex vivo and in vitro study. Invest Ophthalmol Vis Sci. 2004;45(5):1360-8.

12. Herreras JM, Pastor JC, Calonge M, Asensio VM. Ocular surface alteration after long-term treatment with an antiglaucomatous drug. Ophthalmology 1992;99:1082-8.

13. Shimazaki J, Hanada K, Yagi Y, Yamagami J, Ishioka M, Shimmura S, et al. Changes in ocular surface caused by antiglaucomatous eyedrops: prospective, randomised study for the comparison of $0.5 \%$ timolol v $0.12 \%$ unoprostone. Br J Ophthalmol. 2000;84(11):1250-4.

14. Lemp MA. Report of the National Eye Institute/Industry workshop on Clinical Trials in Dry Eyes. CLAO J. 1995;21(4):221-32.

15. Barros JN, Mascaro VL, Gomes JA, Freitas D, Lima, ALH. Citologia de impressão de superficie ocular: técnica de exame e de coloração. Arq Bras Oftalmol. 2001;64(2):127-31.

16. Begley CG, Chalmers RL, Abetz L, Venkataraman K, Mertzanis P, Caffery $\mathrm{BA}$, et al. The relationship between habitual patient-reported symptoms and clinical signs among patients with dry eye of varying severity. Invest Ophthalmol Vis Sci. 2003;44(11):4753-61.

17. Liesegang TJ. Conjunctival changes associated with glaucoma therapy: implications for the external disease consultant and the treatment of glaucoma. Cornea. 1998;17(6):574-83.

18. Realini T, Fechtner RD. 56,000 ways to treat glaucoma. Ophthalmology. 2002;109(11):1955-6.

19. Gobbels M, Spitznas M. Corneal epithelial permeability of dry eyes before and after treatment with artificial tears. Ophthalmology. 1992;99(6):873-8.

20. Cvenkel B, Ihan A. Ocular surface changes induced by topical antiglaucoma monotherapy. Ophthalmologica. 2002;216(3):175-9.

21. Baudouin C, Hamard P, Liang H, Creuzot-Garcher C, Bensoussan L, Brignole F. Conjunctival epithelial cell expression of interleukins and inflammatory markers in glaucoma patients treated over the long term. Ophthalmology. 2004;111(12):2186-92.

22. Hay EM, Thomas E, Pal B, Hajeer A, Chambers H, Silman AJ. Weak association between subjective symptoms or and objective testing for dry eyes and dry mouth: results from a population based study. Ann Rheum Dis. 1998;57(1):20-4.

23. Lucca JA, Nunez JN, Farris RL. A comparison of diagnostic tests for keratoconjunctivitis sicca: lactoplate, Schirmer, and tear osmolarity. CLAO J. 1990;16(2):109-12.

24. McCarty CA, Bansal AK, Livingston PM, Stanislavsky YL, Taylor HR. The epidemiology of dry eye in Melbourne, Australia. Ophthalmology. 1998; 105(6):1114-9.

\title{
Programa de Educação Continuada (P.E.C.) do C.B.O. CD №9 (Ambliopia)
}

\author{
Correção
}

Correção: Na referência a Adjuvantes, na seção de Tratamento, a dose correta de administração da levodopa é a de $0,70 \mathrm{mg} / \mathrm{kg} / \mathrm{dia}$, dividida em três vezes, não como a divulgada (70 mg/kg/dia). 